\title{
Immune presensitization and local intrauterine defences as determinants of success or failure of murine interspecies pregnancies
}

\author{
D. A. Clark*, B. A. Croy†, J. Rossant $\uparrow$ and G. Chaouat \\ *Department of Medicine, McMaster University, 1200 Main Street West, Hamilton, Ontario, \\ Canada L8N 3Z5; †Department of Biological Sciences, Brock University, St Catherines, Ontario, \\ Canada L2S 3A1; and $\ddagger$ Institut Curie, 26 rue d'Ulm, 75231 Paris Cedex 05, France
}

\begin{abstract}
Summary. Putatively immuno-incompetent $M u s$ musculus females exhibited failure to support pregnancy of $M$ us caroli embryos. These results for $M$. musculus females (i.e. treated by cyclosporine $\mathrm{A}$, of the $n u / n u$ genotype, and as an interspecies chimaera) can be explained in immunological terms. Mus musculus females possessed pre-sensitized cytotoxic T cells against $\mathrm{Mus}$ caroli antigens. $\mathrm{Nu} / \mathrm{nu}$ mice possessed activated NK cells and macrophages, and selectively discriminated against $M$ us caroli embryos early in pregnancy unlike normal $+/+$ females; the requirement for $T$ cells to activate nonspecific cytotoxic effector mechanisms was bypassed in $n u / n u$ mice. Mus caroli are not inbred, and interspecies chimaeras which are tolerant of the antigens on the Mus musculus donor strain were not tolerant of cells from unrelated $M$ us caroli. Interspecies chimaeras also behaved as if they were pre-sensitized to Mus caroli. Our results show that Mus caroli embryos recruit fewer active suppressor cells even when gestating in Mus caroli decidua as compared to Mus musculus embryos in Mus musculus decidua and that the ability of Mus caroli placental cells to directly inhibit cytotoxic effector cell killing was inherently less than the inhibitory activity of placental cells from $M u s$ musculus. Mus caroli embryos therefore appear to be less well defended against maternal immune attack even when gestating in a uterus possessing compatible $M u s$ caroli decidual tissue.
\end{abstract}

\section{Introduction}

Semiallogeneic pregnancy which occurs as a result of mating between histoincompatible individuals belonging to the same species is generally successful and there are few animal models with which natural mating leads to a moderate abortion rate (Clark, 1985; Clark et al., 1985). Many types of interspecies pregnancies, in contrast, tend to have a high failure rate. Sheep $\times$ goat matings, and pregnancies created by transferring donkey embryos into horses, usually result in intrauterine destruction of the embryo associated with an infiltration by maternal mononuclear cells at the endometrial-trophoblastic interface reminiscent of the histological picture of graft rejection (Hancock, McGovern \& Stamp, 1968; Allen, 1982). Furthermore, repeat pregnancies of the same type fail more rapidly and a similar accelerated abortion can be achieved by immunization with the cells of the male, a finding suggestive of immunological memory (McGovern, 1973; Allen, 1982). However, some types of interspecies blastocyst transfers do lead to successful pregnancy (Allen, 1982; Bennett \& Foster, 1985; Kydd, Boyle, Allen, Shepherd \& Summers, 1985) and it is important to understand the mechanisms that determine the success of xenoembryo transfer as a prelude to preserving endangered species by blastocyst transfer to xenogeneic recipients.

We have investigated a murine model of xenogeneic pregnancy failure created by transferring 
blastocysts from one species of mouse (Mus caroli) into the uterus of another species, the laboratory mouse (Mus musculus). The Mus caroli embryos implant and develop for about 5 days whereupon they are infiltrated by maternal mononuclear cells and resorb. Although the nature of the initial infiltrate is unclear, at later times when the embryos are necrotic we have demonstrated that maternal cytotoxic T lymphoblasts (CTL) with a degenerate (Wilson \& Shortman, 1984) or pan-specific pattern of killing are present within the dead embryos (Croy, Rossant \& Clark, 1982, 1985; Clark, Slapsys, Croy \& Rossant, 1984).

Mus caroli embryos will survive to term in the Mus musculus uterus if enveloped in Mus musculus trophoblast. Therefore, the trophoblast must play a key role in determining the outcome of the xenopregnancy (Rossant, Croy, Clark \& Chapman, 1983). During successful semiallogeneic pregnancy, non-T suppressor cells develop in uterine decidua at the implantation site. Local active suppressor cells are markedly scarce at the Mus caroli implant sites in the Mus musculus uterus 5 days after implantation (Clark et al., 1983). Since these local suppressor cells appear to be activated or recruited by trophoblast cells, we have proposed that the Mus caroli embryos may be immunologically rejected due to a species restriction that prevents suppressor cell recruitment by the xenogeneic trophoblast cells (Clark et al., 1983; Clark \& Slapsys, 1985; Slapsys, Beeson \& Clark, 1985). However, failure of trophoblast for biological reasons in the xenogeneic environment could result in embryo death due to malnutrition and anoxia, with the trophoblast becoming permeable to infiltrating leucocytes and lymphoid cells. Embryonic death might then occur whether or not there was a maternal immune response (Clark, 1985).

In the present study we have investigated the immunological basis for the failure of $M$. caroli embryos in putatively immunoincompetent $M$. musculus mice.

\section{Materials and Methods}

Mice. Embryo transfer and chimaera production using outbred Mus caroli and Mus musculus have been described in detail elsewhere (Croy et al., 1982, 1985). CDI and CDI $n u / n u$ mice were purchased from Charles River; DBA/2 and $\mathrm{C} 3 \mathrm{H} / \mathrm{He}$ mice were obtained from the Jackson Laboratories, Bar Habor, Maine. $\mathrm{C} 3 \mathrm{H} \times \mathrm{DBA} / 2\left(\mathrm{C} 3 \mathrm{D} 2 \mathrm{~F}_{1}\right)$ mice were bred in our unit. $\mathrm{C} 3 \mathrm{H} / \mathrm{He}$, BALB/c, and Mus caroli were also obtained from the IRCS breeding facility at Villejuif and CSEAL-CNRS (Orleans) breeding unit from the nucleus of Dr J. Bonhomme.

Immunological methods. Delayed-type hypersensitivity was tested by the foot-pad swelling technique. Briefly, the thickness of the right and left hind footpads was measured using a pressure sensitive micrometer, and $20 \mu \mathrm{l}$ of medium or test cells (usually spleen cells) were injected into the right and left pad. After $24 \mathrm{~h}$, the thickness was again measured and the difference in swelling due to the cellular challenge (i.e. increment with cells - increment with medium alone) was determined. Medium used throughout the study was alpha-MEM supplemented to contain $10 \%$ fetal bovine serum, 100 i.u. penicillin/ml, $100 \mu \mathrm{g}$ streptomycin $/ \mathrm{ml}$, and $5 \times 10^{-5} \mathrm{M}-2$-mercaptoethanol. Sterile cell suspensions were prepared as previously described by gently pressing the spleens through a 60-mesh stainless-steel screen (Clark et al., 1983).

Mixed lymphocyte cultures were performed by mixing $3 \times 10^{6}$ spleen cells from one type of mouse (the responder) with $1 \times 10^{6}$ irradiated histoincompatible spleen cells (stimulator cells) in $3 \mathrm{ml}$ medium in $17 \times 100 \mathrm{~mm}$ plastic tubes. After $4-5$ days at $37^{\circ} \mathrm{C}$ in $7 \% \mathrm{CO}_{2}$, the cell pellet was tested for its ability to lyse ${ }^{51} \mathrm{Cr}$-labelled tumour cells (YAC) or lymphoblasts that had been generated by growing spleen cells from the stimulator strain of mouse in medium with concanavalin $\mathrm{A}$ for 3 days as described elsewhere (Croy et al., 1982). After $4 \mathrm{~h}$ incubation at $37^{\circ} \mathrm{C}$, an aliquant of supernatant was removed and the c.p.m. of ${ }^{51} \mathrm{Cr}$ were measured in a gamma counter. Percentage specific release was determined using the standard formula, 


$$
P=100 \% \times \frac{\text { (c.p.m. released with MLC cells }- \text { c.p.m. released spontaneously) }}{\text { (c.p.m. released by NP-40 - c.p.m. released spontaneously) }}
$$

In some experiments the titration curves were computer analysed to determine cytotoxic cell activity in terms of lytic units (Clark et al., 1983).

A soluble suppressor factor was prepared from cell suspensions made from the decidua of Day 14.5-15.5 allopregnant Mus musculus or Mus caroli (i.e. Mus caroli $\times$ Mus caroli) (Slapsys \& Clark, 1983; Clark, Chaput, Walker \& Rosenthal, 1986). The cell-free supernatants were tested for their ability to suppress the generation of cytotoxic cells in the mixed lymphocyte cultures.

Limiting dilution experiments were conducted to determine the frequency of CTL precursors against Mus caroli and against Mus musculus. Small numbers of responding spleen cells were incubated in V-bottom microtray wells with $2 \times 10^{5}$ irradiated stimulator cells plus a $10 \%$ concentration of lectin-free interleukin 2 (IL-2) (Cellular Products, Buffalo, NY, U.S.A.). IL-2 provides the 'help' needed for the precursors of CTL to proliferate into a clone of sufficient size to be detectable. Detection of CTL activity was achieved by adding $2000{ }^{51} \mathrm{Cr}$-labelled target cells to each well after 6 days of culture and those wells showing ${ }^{51} \mathrm{Cr}$-release greater than the spontaneous release +2 standard deviations after $4 \mathrm{~h}$ at $37^{\circ} \mathrm{C}$ were scored as positive. The frequency of precursors was calculated by fitting the data to the Poisson formula by using the method of maximum likelihood (Porter \& Berry, 1964).

In some experiments, a $\mathrm{C} 3 \mathrm{H}$ embryonic cell line with trophoblastic features derived from placenta ('B6' cells) (Beeson, Daynes, Weinert \& Gahring, 1984) were used as target cells to test for effector activity. This was done either by ${ }^{51} \mathrm{Cr}$-release as described above or by measuring the effect of irradiated ( $1500 \mathrm{R}{ }^{60} \mathrm{Co}$ ) effector populations on proliferation of $\mathrm{B} 6$ cells in U-bottomed 96-well trays as assessed by incorporation of $\left[{ }^{3} \mathrm{H}\right]$ thymidine. Briefly, $1 \times 10^{4}$ freshly trypsinized cultured 'B6' cells were seeded with or without splenocytes and after $48 \mathrm{~h} 0.1 \mu \mathrm{Ci}\left[{ }^{3} \mathrm{H}\right.$ ] thymidine was added. After $12-18 \mathrm{~h}$, the incorporated counts were determined by harvesting on to a glass fibre filter (Skatron), and counting in a liquid scintillation counter.

Placental cell suspensions from Day $14 \cdot 5-15 \cdot 5$ of pregnancy were presented by collagenase digestion as described elsewhere (Chaouat \& Kolb, 1984) and tested for their ability to block lysis of YAC target cells by lymphokine-activated killer cells (LAKs). The LAKs were generated by incubating spleen cells for 4-7 days in culture medium supplemented with IL-2 derived from PMA-stimulated EL-4 cells (Kolb, Chaouat \& Chassoux, 1984). This IL:2 was kindly provided by Dr J. P. Kolb, Institut Curie, Paris, France. The washed LAKs were added with placental cells to the assay wells containing ${ }^{51} \mathrm{Cr}$-labelled YAC targets, and $4 \mathrm{~h}$ later, the amount of isotope release was determined.

\section{Results}

Mus musculus are presensitized to Mus caroli

It has previously been reported that Mus caroli xenoembryos invariably failed in cyclosporine A-treated Mus musculus females, no matter how high the dose of drug (Croy et al., 1985). However, once the dose had reached $15 \mathrm{mg} / \mathrm{kg} /$ day, normal alloembryos began to die and at a dose of $50 \mathrm{mg} / \mathrm{kg} /$ day, there was complete lethality in agreement with the observations of Ryffel (1982). It was important to know whether or not the cyclosporine A was an effective suppressant of a putative Mus musculus anti-caroli immune response. Cyclosporine $A$ at a dose of $7 \cdot 5-15 \mathrm{mg} / \mathrm{kg} / \mathrm{day}$ can effectively inhibit a primary immune response to an allograft, but is frequently ineffective if there is pre-sensitization (Homan, Fabre, Williams, Millard \& Morris, 1980; Horsburgh, Wood \& Brent, 1980; Gratwohl, Forster \& Speck, 1981). Therefore, the foot-pad swelling test was done to test for pre-existing sensitization of Mus musculus against Mus caroli antigens. As illustrated in Table 1, in 
all 3 experiments, delayed-type hypersensitivity to Mus caroli cells was demonstrated. In contrast, in 2 reciprocal experiments in which Mus caroli were tested for sensitization to Mus musculus, no significant hypersensitivity was found (net specific swelling of $5 \cdot 0 \pm 8 \cdot 1(\mathrm{~N}=5)$ and $15 \cdot 5 \pm 10 \cdot 2$ $(\mathrm{N}=5)$; the latter experiment contained an outlier that increased mean swelling but also the s.e.m.). These results suggested that Mus musculus embryos might be destroyed less rapidly in the uterus of Mus caroli, as previously reported (Croy et al., 1985).

Table 1. Effect of challenge cells from Mus caroli or Mus musculus $\left(\mathrm{CD1}, \mathrm{C} 3 \mathrm{D}_{2} \mathrm{~F}_{1}\right)$ on foot-pad swelling of $\mathrm{C} 3 \mathrm{H}$ and $\mathrm{CD} 1$ (M. musculus) mice

\begin{tabular}{|c|c|c|c|c|}
\hline $\begin{array}{c}\text { Test } \\
\text { animal }\end{array}$ & $\begin{array}{l}\text { No. of } \\
\text { mice }\end{array}$ & $\begin{array}{c}\text { Cell } \\
\text { challenge } \\
\text { given }\end{array}$ & $\begin{array}{l}\text { Net swelling } \\
(\text { mean } \pm \text { s.e.m.) } \\
\left(\times 10^{-2} \mathrm{~mm}\right)\end{array}$ & $\begin{array}{c}\text { Net specific } \\
\text { swelling } \\
\left(\times 10^{-2} \mathrm{~mm}\right)\end{array}$ \\
\hline $\mathrm{C} 3 \mathrm{H}\left(\mathrm{H}-2^{\mathbf{k}}\right)$ & $\begin{array}{l}4 \\
4\end{array}$ & $\begin{array}{l}3 \times 10^{7} \text { Mus caroli } \\
3 \times 10^{7} \mathrm{CD} 1\left(\mathrm{H}-2^{\mathrm{b}}\right)\end{array}$ & $\left.\begin{array}{r}13 \cdot 5 \pm 3 \cdot 9 \\
-1.0 \pm 4 \cdot 4\end{array}\right\}$ & $14 \cdot 5 \pm 5 \cdot 9^{*}$ \\
\hline $\mathrm{C} 3 \mathrm{H}\left(\mathrm{H}-2^{\mathbf{k}}\right)$ & $\begin{array}{l}6 \\
6\end{array}$ & $\begin{array}{l}2 \times 10^{7} \text { Mus caroli } \\
2 \times 10^{7} \mathrm{C} 3 \mathrm{D} 2 \mathrm{~F}_{1}\left(\mathrm{H}-2^{\mathrm{kd}}\right)\end{array}$ & $\left.\begin{array}{r}25.0 \pm 2.8 \\
9.8 \pm 4.9\end{array}\right\}$ & $15 \cdot 2 \pm 5 \cdot 6^{*}$ \\
\hline $\mathrm{CD} 1\left(\mathrm{H}-2^{\mathrm{b}}\right)$ & $\begin{array}{l}7 \\
5\end{array}$ & $\begin{array}{l}2 \times 10^{7} \text { Mus caroli } \\
2 \times 10^{7} \mathrm{C} 3 \mathrm{D} 2 \mathrm{~F}_{1}\left(\mathrm{H}-2^{\mathrm{kd}}\right)\end{array}$ & $\left.\begin{array}{r}21 \cdot 9 \pm 4 \cdot 2 \\
7 \cdot 4 \pm 3 \cdot 4\end{array}\right\}$ & $14 \cdot 5 \pm 5 \cdot 4^{*}$ \\
\hline
\end{tabular}

${ }^{*} P<0.05$ (Student's $t$ test) for swelling induced by Mus caroli spleen compared to effect of $M$ us musculus control spleen cells.

\section{CTL precursor frequency as a test for presensitization}

Unidirectional graft rejection models have been described for thyroid and islet cell allografts in B10.S and B10.S (7R) mice in which a graft in one direction fails (B10.S into B10.S (7R)) but succeeds in the opposite direction (B10.S (7R) into B10.S) (Isakov \& Bach, 1985). The unidirectional rejection was explained by the finding that the accepting (i.e. non-rejecting) recipient had only $25 \%$ as many CTL precursors reactive with B10.S (7R) antigens as the B10.S (7R) rejecting strain had to B10.S (Isakov \& Bach, 1985). Therefore, the CTL precursor frequency for Mus musculus and Mus caroli against each others antigens was determined. Table 2 illustrates that $M u s$ caroli had a much lower CTL precursor frequency against $\mathrm{C} 3 \mathrm{H}$ compared to $\mathrm{C} 3 \mathrm{H}$ against $\mathrm{Mus}$ caroli. A similar difference in CTL precursor frequency was found when Mus caroli were compared to a second Mus musculus strain, CD1. Thus differences in CTL precursor frequencies between $M u s$ musculus and Mus caroli were comparable to those seen in the unidirectional thyroid graftrejection system. Furthermore, if IL-2 alone was added to the spleen cells in the absence of antigenic stimulators, $\mathrm{C} 3 \mathrm{H}$ produced cytotoxic effectors that specifically killed Mus caroli lymphoblasts whereas Mus caroli spleen cells incubated in IL-2 failed to produce any killer activity (Table 2). Similar results were obtained using CD1 + IL-2. The activation of specific killing by IL-2 has been shown to result from the reactivation of memory CTL cells (Yoshimoto, Kashima, Okada, Amikura \& Hamuro, 1985).

Therefore, both the foot-pad swelling data and the CTL precursor data indicated that Mus musculus possessed pre-existing immunity to Mus caroli. This pre-existing immunity could explain the failure of cyclosporine to block resorption of Mus caroli embryos in the Mus musculus uteri, the rapidity of the rejection of Mus caroli embryos in Mus musculus, and the non-reciprocal nature of the transfer system.

\section{Studies with putatively immunoincompetent nude mice}

It has previously been shown that Mus caroli embryos resorb in the uterus of CD1 $n u / n u$ females, whereas CD1 Mus musculus embryos gestate successfully (Croy et al., 1985). Mice of the 
Table 2. Limiting dilution analysis of Mus caroli and Mus musculus CTL precursors

\begin{tabular}{|c|c|c|c|c|c|c|c|c|}
\hline \multirow{2}{*}{$\begin{array}{l}\text { Responder } \\
\text { spleen } \\
\text { cells }\end{array}$} & \multirow[b]{2}{*}{ Stimulator } & \multirow[b]{2}{*}{ Target } & \multicolumn{4}{|c|}{$\begin{array}{l}\text { No. of } \\
\text { responder cells per well* }\end{array}$} & \multirow{2}{*}{$\begin{array}{l}\text { CTL precursor } \\
\text { frequency } \\
\text { (95\% confidence } \\
\text { interval) }\end{array}$} & \multirow{2}{*}{$\begin{array}{c}\text { CTL } \\
\text { precursor } 10^{6} \\
\text { spleen cells }\end{array}$} \\
\hline & & & 3704 & 1235 & 412 & 137 & & \\
\hline \multirow[t]{4}{*}{ Mus caroli } & \multirow{2}{*}{$\mathrm{C} 3 \mathrm{H}+\mathrm{IL}-2$} & M. caroli & $3 / 12$ & $1 / 12$ & $1 / 12$ & $0 / 11$ & - & - \\
\hline & & C3H & $9 / 12$ & $6 / 12$ & $1 / 12$ & $1 / 12$ & $1 / 2329(1455-3709)$ & 429 \\
\hline & \multirow{2}{*}{ IL-2 } & M. caroli & $1 / 12$ & $0 / 12$ & $0 / 12$ & $1 / 12$ & - & - \\
\hline & & $\mathrm{C} 3 \mathbf{H}$ & $2 / 12$ & $2 / 12$ & $0 / 12$ & $0 / 12$ & - & - \\
\hline \multirow[t]{4}{*}{$\mathrm{C} 3 \mathrm{H}$} & \multirow{2}{*}{ M. caroli + IL-2 } & M. caroli & $12 / 12$ & $10 / 12$ & $4 / 12$ & $1 / 12$ & $1 / 819(508-1318)$ & 1221 \\
\hline & & $\mathrm{C} 3 \mathrm{H}$ & $1 / 11$ & $0 / 11$ & $0 / 12$ & $1 / 12$ & - & - \\
\hline & \multirow{2}{*}{ IL-2 } & M. caroli & $10 / 12$ & $7 / 12$ & $2 / 12$ & $1 / 12$ & $1 / 1804(1112-2927)$ & 554 \\
\hline & & $\mathrm{C} 3 \mathrm{H}$ & $3 / 12$ & $0 / 12$ & $2 / 11$ & $0 / 12$ & - & - \\
\hline
\end{tabular}

*The no. of wells scored per total tested at the indicated number of responder cells is shown. Spontaneous release of the Con A blast target cells was determined from wells containing irradiated stimulators + IL-2 or IL-2 in medium alone.

$n u / n u$ genotype lack an effector $\mathrm{T}$ cell system and will bear skin allografts and skin xenografts, including Mus caroli, without signs of rejection, and it could therefore be presumed that failure of $M u s$ caroli in the $n u / n u$ uterus is not mediated by CTL. However, $n u / n u$ mice possess activated NK cells and, more importantly, activated macrophages that render them more resistant to intracellular infections and capable of rejecting transplants of xenogeneic embryonic tumours and melanomas (Solter \& Damjanov, 1979; Sharp \& Colson, 1984; Rousseau-Merck et al., 1985; Jacubovich, Cabrillat, Gerlier, Bailly \& Dore, 1985). During the allograft rejection response in normal immunocompetent mice, sensitized $\mathrm{T}$ cells activate macrophages and NK cells. This requirement for sensitized $T$ cells to produce NK and macrophage activation is bypassed in $n u / n u$ mice. Since the uterus is replete with macrophages (Matthews, Adams \& Searle, 1985), and since macrophages have been reported to be unusually cytolytic towards xenogeneic target cells (Cabilly \& Gallily, 1981), we have reviewed the data obtained from transfers of Mus caroli and Mus musculus blastocysts to the $+/+$ and $n u / n u$ uterus for evidence of selection against xenogeneic $M u s$ caroli embryos in $n u / n u$ recipients.

The implantation rate of Mus caroli as compared to Mus musculus in $+1+$ recipients in experiments done over a $1 \frac{1}{2}$ - to 2 -year period was $\operatorname{similar}(66 / 83=80 \%$ vs $70 / 78=90 \%)$. In contrast, the implantation rate as assessed on Day $10.5 \mathrm{in} n u / n u$ recipients (Croy et al., 1982) was only $61 \%(17 / 28)$ for Mus caroli blastocysts as compared to $16 / 19(84 \%)$ for Mus musculus $(P<0.05$ by Fisher's Exact test). A comparison of transfers over a $1 \frac{1}{2}$-year period for Mus caroli and Mus musculus blastocysts showed that all the Mus caroli embryos were dead at the time of analysis, a more rapid demise than had occurred in $+/+$ recipients (Croy et al., 1985). These accumulated data suggested that $n u / n u$ mice differed from $+1+$ animals and may have been able to discriminate against Mus caroli embryos at the implantation and early post-implantation stages of pregnancy.

To test for activated non-specific effector cells against embryonic placental cells in $n u / n u$ mice, we used a C3H placental cell line ('B6') which grows transiently and regresses in $n u / n u$ mice. B6 target cells proved susceptible to killing by LAK but not by NK cells in normal spleen (4/4 experiments) (Exp. 1, Table 3) and $n u / n u$ spleen cells were cytotoxic for 'B6' targets as compared to $+/+$ splenocytes ( $2 / 2$ experiments) and could markedly inhibit the growth of 'B6' cells in vitro (3/3 experiments) (Exps $2 \& 3$, Table 3). The identity of the effector population in the $n u / n u$ mice was not determined in these studies. The flat titration curves from cýtotoxicity shown in Exp. 2 were reminiscent of the flat titration curves seen with low-level cytotoxic activity of in-vivo allosensitized cells (Clark, Phillips \& Miller, 1977). 
Table 3. Effect of different types of host effector cells on the 'B6' placental cell line in vitro

\begin{tabular}{|c|c|c|c|c|}
\hline \multirow[b]{2}{*}{ Test system } & \multirow{2}{*}{$\begin{array}{l}\text { Effector to } \\
\text { target ratio }\end{array}$} & \multicolumn{3}{|c|}{$\%$ Cytotoxicity (mean \pm s.e.m.) with: } \\
\hline & & LAK & $+/+$ spleen & $n u / n u$ spleen \\
\hline${ }^{51} \mathrm{Cr}$-release, $5 \mathrm{~h}$ & $\begin{array}{r}50: 1 \\
25: 1 \\
12 \cdot 5: 1\end{array}$ & $\begin{array}{r}26.9 \pm 3.8 \\
15.9 \pm 1.0 \\
8.8 \pm 1.2\end{array}$ & $\begin{array}{r}-0.9 \pm 0.9 \\
0.1 \pm 0.5 \\
0.6 \pm 0.2\end{array}$ & $\begin{array}{l}\text { nd } \\
\text { nd } \\
\text { nd }\end{array}$ \\
\hline${ }^{51} \mathrm{Cr}$-release, $5 \mathrm{~h}$ & $\begin{array}{r}50: 1 \\
25: 1 \\
12 \cdot 5: 1\end{array}$ & $\begin{array}{l}\text { nd } \\
\text { nd } \\
\text { nd }\end{array}$ & $\begin{array}{l}- \\
-\end{array}$ & $\begin{array}{l}10 \cdot 2 \pm 2 \cdot 1^{*} \\
13 \cdot 2 \pm 1 \cdot 8 \\
13 \cdot 1 \pm 1 \cdot 3\end{array}$ \\
\hline$\left[{ }^{3} \mathrm{H}\right]$ Thymidine incorporation & $\begin{array}{l}1: 1 \\
1: 1 \dagger\end{array}$ & $\begin{array}{l}48 \cdot 8 \pm 2 \cdot 5 \\
52 \cdot 0 \pm 2 \cdot 2\end{array}$ & $\begin{array}{r}2.9 \pm 6.9 \\
13.4 \pm 9.4\end{array}$ & $\begin{array}{l}47 \cdot 4 \pm 5 \cdot 1 \\
42 \cdot 6 \pm 2 \cdot 6\end{array}$ \\
\hline
\end{tabular}

Values are mean \pm s.e.m.; nd = not done.

*c.p.m. released with $+/+$ spleen cells alone was used to compute spontaneous release value.

$\dagger$ Treated with $1500 \mathrm{R}$ before addition to culture. Values represent percentage decrease in c.p.m. incorporated compared to wells containing 'B6' cells and medium alone.

\section{Putatively tolerant interspecies chimaeric mice are not tolerant of Mus caroli}

An alternative strategy to prevent immunological rejection of Mus caroli embryos is to use female recipients that are immunologically tolerant of $M u s$ caroli antigens. It has been possible to create mice that are chimaeric, being composed of both Mus musculus and Mus caroli tissues. These chimaeras should be tolerant of the species antigens of both Mus musculus and Mus caroli. However, Mus musculus embryos were found to survive in the uterus of the chimaera whereas the Mus caroli embryos failed (Croy et al., 1985). Before concluding that non-immunological mechanisms led to the demise of the Mus caroli embryos, it is important to know whether the chimaeras were, in fact, immunologically tolerant. To examine this issue, the chimaeras were tested for their ability to reject skin grafts in vivo and their spleen cells were tested for the ability to generate CTL in vitro. As shown in Table 4, the chimaeric spleen cells were able to mount a CTL response against pooled Mus caroli stimulator cells. Six chimaeras were tested with similar results. Furthermore, Mus caroli skin grafts were rejected by the chimaeras (Croy et al., 1985). Mus caroli are not inbred and therefore these results could be explained by the skin graft donors being allogeneic to the parental contribution to the chimaera. However, addition of IL-2 to the chimaeric spleen cells also led to the generation of CTL specific for Mus caroli antigens (Table 4) and the splenic lymphocytes from the chimaeras therefore behaved as if they had been presensitized to Mus caroli lymphoblast antigens.

\section{Mus caroli have deficient defences against rejection}

Allogeneic matings are generally successful. The antigenic differences between individual Mus caroli animals that allow one $M$ us caroli to generate CTL against another $M$ us caroli are equivalent to allogeneic differences between different strains of inbred Mus musculus. Furthermore, it has been shown that CTL against xenoantigens also manifest the specificity typical of CTL against alloantigens (Burakoff, Ratnofsky \& Benacerraf, 1977). CTL generated by chimaeras against either $M u$ s musculus or Mus caroli antigens should therefore be viewed as allospecific CTL. During normal allogeneic pregnancy in Mus musculus, local active suppression by suppressor cells in decidua and by placental cells inhibits CTL development and killing activity (Kolb et al., 1984; Clark, 1985) and in a chimaera, both Mus musculus and Mus caroli trophoblast should be able to recruit suppressors provided the decidua is chimaeric (Clark \& Slapsys, 1985). This suppression in allopregnant Mus musculus is sufficient to prevent rejection even when the female has been immunized against the MHC antigens of the father (Clark, 1985; Clark et al., 1985). Since it has been shown in Table 4 
Table 4. Immune reactivity of CD1 Mus musculus-Mus caroli chimaeras

\begin{tabular}{lcccc}
\hline & & \multicolumn{3}{c}{ Target cell } \\
\cline { 3 - 5 } Test system & Antigen used & Mus caroli & CD1 & DBA $/ 2$ \\
\hline \multirow{2}{*}{ Tube MLC } & CD1 & $4 \cdot 9 \pm 1 \%^{\mathrm{a}}$ & $6 \cdot 1 \pm 1 \%$ & $0 \%$ \\
& DBA/2 & $23 \cdot 9 \pm 2 \%$ & $15 \cdot 8 \pm 1 \%$ & $54 \cdot 6 \pm 1 \%$ \\
& Mus caroli & $44 \cdot 8 \pm 2 \%$ & $9 \cdot 9 \pm 0 \cdot 1 \%$ & $0 \%$ \\
Limiting & IL-2 only & $1-5381$ & 0 & 0 \\
\multirow{2}{*}{ Dilution } & IL-2 only & $(2855-10141)^{*}$ & & 0 \\
& & $(3352-13601)^{*}$ & 0 & 0 \\
\hline
\end{tabular}

Values are $\%$ specific release of ${ }^{51} \mathrm{Cr}$ from Con A lymphoblast targets (mean \pm s.e.m.) at an effector to target ratio of 30:1 from one of 6 experiments testing spleen cells of individual chimaeras. Spontaneous release was determined in the presence of an equivalent ratio of cells from a syngeneic (i.e. CDI + irradiated CD1) MLC. Of the 6 chimaeric females tested, the spleen cells of 3 were tested for composition by GPI typing. On this basis, the chimaeras were 15,30 , and $35 \%$ caroli. The values shown were obtained from the $35 \%$ caroli chimaera. In a 4 th animal, the lymph node cells were typed and were found to be $80 \%$ caroli.

*Values show CTL precursor frequency against each target and $95 \%$ confidence interval from 2 independent experiments of the type illustrated in Table 2. One chimaera was used in each experiment. Only Mus caroli targets showed significant killing. GPI analysis was not done on these chimaeras.

Table 5. Relative potency of supernatants from decidua of pregnant Mus caroli and Mus musculus

\begin{tabular}{lcc}
\hline \multirow{2}{*}{$\begin{array}{c}\text { Source of supernatant }(1 / 100) \\
\text { added to MLC culture }\end{array}$} & \multicolumn{2}{c}{$\%$ Supression of CTL generation } \\
\cline { 2 - 3 } & C3H anti-BALB/c & C57BL/6 anti-BALB/c \\
\hline None (medium) & $0 \pm 3 \cdot 4$ & $0 \pm 3 \cdot 3$ \\
Mus caroli $\times$ Mus caroli pregnancy & $-2 \pm 3 \cdot 1$ & $38 \cdot 6 \pm 2 \cdot 6$ \\
Mus caroli $\times$ Mus caroli pregnancy & $9 \cdot 3 \pm 3 \cdot 5$ & $42 \cdot 9 \pm 3 \cdot 2$ \\
C3H $\times$ DBA/2 pregnancy & $24 \cdot 6 \pm 3 \cdot 8^{*}$ & $88 \cdot 5 \pm 0 \cdot 9^{*}$ \\
C3H $\times$ DBA/2 pregnancy & $17 \cdot 6 \pm 2 \cdot 5^{*}$ & $79 \cdot 1 \pm 1 \cdot 3^{*}$ \\
C3H $\times$ C3H pregnancy & $37 \cdot 1 \pm 2 \cdot 0^{*}$ & $75 \cdot 2 \pm 1 \cdot 8^{*}$ \\
\hline
\end{tabular}

*Significantly greater suppression than by supernatants from pregnant Mus caroli $(P<0.05$; Student's $t$ test). CTL were generated in MLC tissue cultures (C3H + irradiated BALB/c cells $\left(\mathrm{H}-2^{\mathrm{d}}\right)$ plus $\mathbf{1} / 100$ dilution of supernatant). ${ }^{51} \mathrm{Cr}$-labelled YAC that bear $\mathbf{H}-2^{\mathrm{d}}$ determinants were used and as target cells the spontaneous release was determined from cultures containing medium alone. Titration curves were analysed to determine cytotoxic activity in lytic units and the percentage decrease in yield in presence of test supernatant determined with respect to medium control cultures.

that the Mus caroli-Mus musculus chimaeras already possess sensitized CTL precursors against Mus caroli, it was crucial to determine whether the local active suppression generated by a $M u s$ caroli embryo interacting with $M u s$ caroli decidua cells was as effective as the suppression associated with a Mus musculus embryo interacting with Mus musculus decidua. Suppression induced by Mus caroli trophoblast interacting with Mus caroli decidua in a putatively chimaeric uterus should be able to inhibit CTL of both musculus and caroli origin. Therefore, the potency of suppression by decidual cell supernatants from Mus musculus $\times$ Mus musculus pregnancies was compared to that elaborated by decidua associated with Mus caroli $\times$ Mus caroli pregnancies. The soluble suppressor activity obtained from the decidua associated with a successful Mus caroli in 


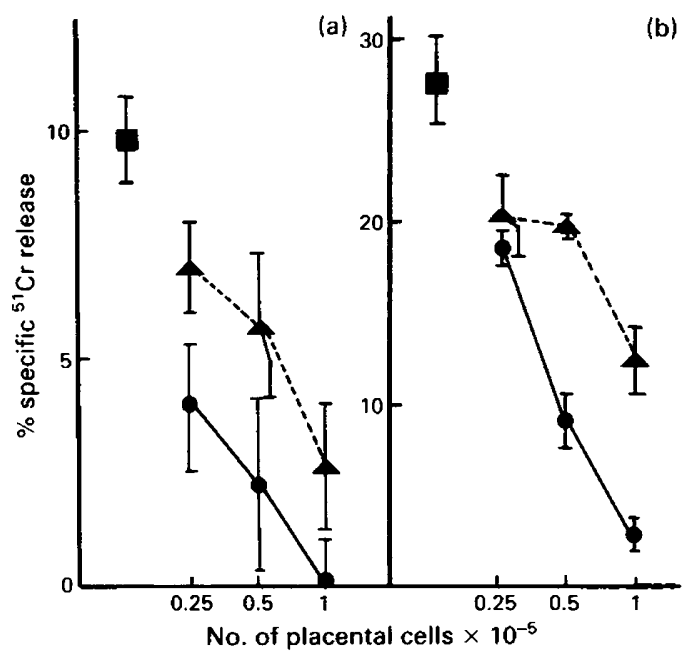

Fig. 1. Effect of placental cells on lymphokine-activated killer cells. (a) Lysis by Mus musculus lymphocyte cultures in IL-2 alone ( $\mathbf{\square}$ ) or with Mus musculus placental cells (-), or Mus caroli placental cells ( $\mathbf{\Delta}$ ). (b) Lysis by Mus caroli splenocytes cultured in IL-2 without ( $\boldsymbol{\square}$ ) or with placental cells $(\boldsymbol{O}, \boldsymbol{\Delta})$. Values are mean \pm s.e.m.

Mus caroli allopregnancy was less potent than that obtained from Mus musculus $\times$ Mus musculus allopregnancy (Table 5), an observation that was confirmed in two additional experiments. One would predict that a transferred Mus caroli embryo to a chimaera would not be expected to create the same magnitude of suppression at the implantation site as would a Mus musculus embryo, provided of course, the decidua was not primarily of Mus caroli type. This experiment and typing of the decidua of the chimaera has not been done. Figure 1 shows that the ability of placental cells from Mus caroli to inhibit LAK activity on YAC target cells was also less than the activity of a Mus musculus placental preparation. A similar finding was obtained in a second experiment, indicating that the strength of the local defence system of a Mus caroli embryo is inherently less than that of Mus musculus. In a chimaera, therefore, a Mus caroli embryo would be much less well defended by direct placental suppression and by decidua-associated suppressor activity than would be a Mus musculus embryo.

\section{Discussion}

Previous studies to test the role of the maternal immune system in the destruction of xenogeneic murine pregnancies have shown that resorption occurs even in putatively immunodeficient mice (i.e. cyclosporine-treated mice, $n u / n u$ mice, presumptively tolerant interspecific chimaeras). It was suggested that the xenogeneic embryos succumb due to a biological defect in trophoblast-uterine interaction and that the maternal immune system plays a secondary role in destruction of the fetus (Croy et al., 1985). The results presented in this paper examine certain assumptions about the putatively immunologically unreactive recipient mice upon which previous conclusions were based. The discovery of pre-sensitization of Mus musculus against $M$ us caroli antigens explains why embryo destruction may occur so rapidly in Mus musculus hosts and why the reaction is not suppressed by cyclosporine A. The explanation for pre-sensitization is unknown but may represent sensitization by a cross-reactive antigen such as a virus that would be seen in association with 'self MHC' as a modified-self (allo- or xeno-antigen). 
Athymic $n u / n u$ mice are certainly competent to reject certain types of grafted tumours, albeit not by a specific adaptive immune response but due to activation of non-specific effector cells. The $n u / n u$ mice clearly may have the ability to discriminate against xenogeneic blastocysts at implantation much earlier in pregnancy than usual and this selective elimination of xenogeneic embryos is consistent with the greater cytotoxic activity of activated macrophages, against xenogeneic target cells (Cabilly \& Galliley, 1981). The finding that $n u / n u$ mice possess cytotoxic and cytostatic inhibitors of an embryonic placental cell line further indicates that these mice possess an active effector mechanism.

Interspecies chimaeric mice have not been found in our study to be tolerant to unrelated $\mathrm{Mus}$ caroli and chimaeras possess pre-sensitization against lymphoblast antigens of unrelated $\mathrm{Mus}$ caroli donor. Mus caroli embryos also generate less local suppressor activity even when gestating in a $M u s$ caroli uterus. Together, these results suggest that the Mus caroli embryo may be particularly susceptible to immune destruction even in the chimaeric uterus. Indeed, when Mus caroli $\times$ Mus musculus matings are generated in chimaeras such that the mother is truly tolerant of the Mus caroli genetic material (because it was her own), live $F_{1}$ offspring seem to be produced at a greater than expected number compared to a non-tolerant situation. Only 18 viable hybrids were born from 578 implantations in Mus musculus females inseminated with Mus caroli spermatozoa (3\%); insemination with Mus musculus spermatozoa gave 515 newborns per implant (85\%) (West, Fredo, Papaioannou, Karr \& Chapman, 1977; West, Fredo \& Chapman, 1978). Three chimaeric females inseminated with Mus musculus spermatozoa produced a total of 114 Mus musculus and 15 hybrid offspring in 34 litters (Rossant \& Chapman, 1983). If one assumes an $85 \%$ success rate for Mus musculus implants and an equal number of Mus musculus and hybrid blastocysts, then approximately $15 / 134(11 \cdot 2 \%)$ musculus $\times$ caroli blastocysts should have survived $(15 / 134$ vs $18 / 578$; $P<0.005$ by $\chi^{2}$ ). Indeed, the proportion of hybrid blastocysts implanting in Mus musculus inseminated with Mus caroli spermatozoa appears significantly lower on Days 8-14 than the proportion of Mus musculus $\times$ Mus musculus implants, perhaps due to abnormal and retarded development (West et al., 1977). In a chimaera, therefore, the number of hybrid implantations might be expected to be less than the estimate (134) given above. When hybrids were treated by inseminating chimaeras with Mus caroli spermatozoa, for which Mus caroli antigens not represented in the Mus caroli component of the chimaera would be expected, no successful pregnancies occurred (Rossant \& Chapman, 1983). The number of females studied was too small, however, to allow meaningful conclusions.

Although immune reactivity appears to play an important role in the demise of the xenogeneic embryo in the Mus caroli-Mus musculus system, the exact mechanisms initiating death remain unclear. In the chimaeric uterus, one would expect $M u s$ caroli decidual tissue to exist and to interact with Mus caroli trophoblast. It is therefore unlikely that Mus caroli embryos fail in the chimaeric uterus because of a complete species incompatibility between the decidua and the trophoblast. The hypothesis that Mus caroli blastocysts die in the chimaeric uterus because they are more fastidious is difficult to test experimentally. It seems more likely that a species-restricted ability of trophoblast to recruit local active suppressor cells and a lesser recruitment in a caroli-caroli trophoblastdecidua interaction as compared to musculus-musculus interaction leaves caroli embryos highly susceptible to attack by the sensitized maternal immune system (Clark et al., 1983; Clark \& Slapsys, 1985). Mus musculus embryos, however, would nevertheless be able to survive much longer in the Mus caroli uterus because the magnitude of the immune attack would be less (i.e. Mus caroli are not pre-sensitized to Mus musculus), and because Mus musculus placental cells are more potent inhibitors of Mus caroli effectors than are Mus caroli placental cells (i.e. Mus musculus embryos are intrinsically better defended at the placental level in a Mus musculus or Mus caroli uterus). One prediction from these considerations is that an immunized female Mus caroli should show rapid resorption of a Mus musculus embryo inasmuch as local decidua-associated suppressor cell activity should be absent. This experiment is currently being planned. A second hypothesis to explain xenoembryo death proposes that the maternal immune system actually damages the embryo (and 
trophoblast) such that it cannot effectively defend itself (i.e. generate local active suppression). Whether the actual mechanism of trophoblast dysfunction is mediated by specific antibodies, specific CTL, or non-specific effectors such as LAK and activated macrophage (both activated by lymphokine produced by activated $T$ cells) is unknown. No data yet exist to test the hypothesis but the concept is none the less worthy of investigation because antigen-specific humoral and cellular immune responses to trophoblast antigens seem to occur in early pregnancy (Youtananukorn, Matankasombut \& Osathanondh, 1974; Davies \& Browne, 1985) and anti-trophoblast types of immune reactivity may be modifiable to either increase or decrease reproductive success. Since antigens shared by lymphocytes/lymphoblast and trophoblast cells may be involved in these phenomena (McConnachie \& McIntyre, 1984), it will be important to test whether the Mus carolispecific CTL generated by incubating Mus musculus spleen cells in IL-2 can compromise the function of Mus caroli trophoblast cells.

It is important to understand the nature of the balance between immune reactivity and local defence systems that may determine the success or failure of xenoembryo transfer before extensive attempts are made to gestate embryos from endangered species in xenogeneic or chimaeric recipients. It seems unlikely that the Mus caroli-Mus musculus pair is the only arrangement in which pre-existing hypersensitivity to one parental type occurs. Indeed, our results suggest that testing for such hypersensitivity could predict which xenogeneic blastocyst transfers would be clinically successful.

\section{Supported by Grants from the Medical Research Council of Canada and INSERM.}

\section{References}

Allen, W.R. (1982) Immunological aspects of the endometrial cup reaction and the effect of xenogeneic pregnancy in horses and donkeys. J. Reprod. Fert. Suppl. 31, 57-94.

Beeson, J.H., Daynes, R.A., Weinert, A.M. \& Gahring, L.C. (1984) Tumors arising from injection of cultured murine placental cell lines into normal animals: direct evidence for placental origin of tumors of two histological types. J. Nat. Canc. Inst. 73, 705-709.

Bennett, S.D. \& Foster, W.R. (1985) Successful transfer of a zebra embryo to a domestic horse. Equine vet. $J$. Suppl. 3, 78-79.

Burakoff, S.J., Ratnofsky, S.E. \& Benacerraf, B. (1977) Mouse cytolytic T lymphocytes induced by xenogeneic rat stimulator cells exhibit specificity for $\mathrm{H}-2$ complex alloantigens. Proc. natn. Acad. Sci. U.S.A. 74, 4572-4576.

Cabilly, S. \& Gallily, R. (1981) Non-immunological recognition and killing of xenogeneic cells by macrophages. I. Repertoire of recognition. Immunology 44, $347-355$.

Chaouat, G. \& Kolb, J.P. (1984) Immunoactive products of murine placenta. II. Afferent suppression of maternal cell-mediated immunity by supernatants from short-term cultures of murine trophoblast-enriched cell suspension. Annls Immunol. (Inst. Pasteur) 135C, 205-218.

Clark, D.A. (1985) Materno-fetal relations: a mini review. Immunol. Lett. 9, 239-247.

Clark, D.A. \& Slapsys, R.M. (1985) Immunoregulatory mechanisms in the uterus and survival of the fetus. In Advances in Obstetrics \& Gynecology, Vol. 14, pp. 43-55. Eds V. Toder \& A. E. Beer. S. Karger, Basel.
Clark, D.A., Phillips, R.A. \& Miller, R.G. (1977) Characterization of the cells that suppress the cytotoxic activity of $\mathrm{T}$ lymphocytes. II. Physical properties, specificity, and developmental kinetics of the inhibitory non T cell population. Cellular Immunology 34, 25-37.

Clark, D.A., Slapsys, R.M., Croy, B.A. \& Rossant, J. (1983) Suppressor cell activity in murine decidua correlates with success or failure of murine pregnancies. J. Immunol. 131, 540-542.

Clark, D.A., Slapsys, R.M., Croy, B.A. \& Rossant, J. (1984) Immunoregulation of host-vs-graft responses in the uterus. Immunol. Today 5, 111-115.

Clark, D.A., Slapsys, R.M., Chaput, A., Walker, K., Brierley, J., Daya, S. \& Rosenthal, K.L. (1985) Immunoregulatory molecules of trophoblast and decidual suppressor cell origin at the maternofetal interface. Am. J. reprod. Immunol. Microbiol. (in press).

Clark, D.A., Chaput, A., Walker, K. \& Rosenthal, K. (1986) Active suppression of host-vs-graft reaction in pregnant mice. VI. Soluble suppressor activity obtained from decidua of allopregnant mice blocks the response to IL 2. J. Immunol. 134, 1659-1664.

Croy, B.A., Rossant, J. \& Clark, D.A. (1982) Histological and immunological studies of post-implantation death of Mus caroli embryos in the Mus musculus uterus. J. Reprod. Immunol. 4, 277-293.

Croy, B.A., Rossant, J. \& Clark, D.A. (1985) Effects of alteration of the immunocompetent status of $M u s$ musculus females on the survival of transplanted $M u s$ caroli embryos. J. Reprod. Fert. 74, 479-489.

Davies, M. \& Browne, C.M. (1985) Anti-trophoblast 
antibody response during normal human pregnancy. J. Reprod. Immunol. 7, 285-297.

Gratwohl, A., Forster, J. \& Speck, B. (1981) Skin grafts in rabbits with cyclosporin A: absence of induction of tolerance and unwanted side effects. Transplantation 31, 136-138.

Hancock, J.L., McGovern, P.T. \& Stamp, J.T. (1968) Failure of goat $\times$ sheep hybrids in goats and sheep. J. Reprod. Fert., Suppl. 3, 29-36.

Homan, W.P., Fabre, J.W., Williams, K.A., Millard, P.R. \& Morris, P.J. (1980) Studies of the immunosuppressive properties of cyclosporine $A$ in rats receiving renal allografts. Transplantation 29, 361-366.

Horsburgh, T., Wood, P. \& Brent, L. (1980) Suppression of in vitro lymphocyte activity by cyclosporin $\mathrm{A}$ : existence of a population of drug-resistant cytotoxic lymphocytes. Nature, Lond. 286, 609, 611.

Isakov, N. \& Bach, F.H. (1985) High frequency of splenic anti-class I cytotoxic T lymphocyte precursors correlates with in vivo rejection of $\mathrm{K} / \mathrm{D}$ region disparate thyroid and islet grafts in mice. J. Immunol. 132, $50-56$.

Jacubovich, R., Cabrillat, H., Gerlier, D., Bailly, M. \& Dore, J.F. (1985) Tumourigenic phenotypes of human melanoma lines in nude mice determined by an active antitumor mechanism. Br. J. Cancer 51, 335-345.

Kolb, J.P., Chaouat, G. \& Chassoux, D. (1984) Immunoactive products of placenta. III. Suppression of natural killing. J. Immunol. 132, 2305-2310.

Kydd, J., Boyle, M.S., Allen, W.R., Shepherd, A. \& Summers, P.M. (1985) Transfer of exotic equine embryo to domestic horses and donkeys. Equine vet. J., Suppl. 3, 80-83.

Matthews, C.J., Adams, A.M. \& Searle, R.F. (1985) Detection of macrophages and the characterization of Fc receptor-bearing cells in the mouse decidua, placenta and yolk sac using the macrophage-specific monoclonal antibody F4/80. J. Reprod. Immunol. 7, 315-323.

McConnachie, P.R. \& McIntyre, J.A. (1984) Maternal antipaternal immunity in couples predisposed to repeated pregnancy losses. Am. J. Reprod. Immunol. 5, 145-150.

McGovern, P.T. (1973) The effect of maternal immunization on the survival of goat $\times$ sheep hybrids. $J$. Reprod. Fert. 34, 215-220.

Porter, E.H. \& Berry, R.J. (1964) The efficient design of transplantable tumor assays. Br. J. Cancer 17, 583-595.

Rossant, J. \& Chapman, V. (1983) Somatic and germline mosaicism in interspecific chimeras between $M$ us musculus and Mus caroli. J. Embryol. exp. Morph. 73, 193-205.
Rossant, J., Croy, B.A., Clark, D.A. \& Chapman, V.M. (1983) Interspecific hybrids and chimeras in mice. $J$. exp. Zool. 228, 223-233.

Rousseau-Merck, M.F., Bigel, P., Mouly, H., Flamant, F., Zucker, J.M., Wache, A.C. \& Nezelof, C. (1985) Transplantability in nude mice of embryonic and other childhood tumors. Br. J. Cancer 52, 279-283.

Ryffel, B. (1982) Experimental toxicological studies with cyclosporin A. In Cyclosporin A, pp. 45-75. Ed. B. Sordat. Elsevier Biomedical Press, Amsterdam.

Sharp, A.K. \& Colson, M.J. (1984) The regulation of macrophage activity in congenitally athymic mice. Eur. J. Immunol. 14, 102-105.

Slapsys, R.M. \& Clark, D.A. (1983) Active suppression of host-versus-graft reaction in pregnant mice. $\mathrm{V}$. Kinetics, specificity, and in vivo activity of non-T suppressor cells localized to the genital tract of mice during first pregnancy. Am. J. Reprod. Immunol. 3, 65-71.

Slapsys, R.M., Beeson, J.H. \& Clark, D.A. (1985) Recruitment of a trophoblast-dependent suppressor cell to the implantation site of allopregnant mice. Fedn Proc. Fedn Am. Socs exp. Biol. 44, 1880.

Solter, D. \& Damjanov, I. (1979) Teratocarcinomas rarely develop from embryos transplanted into athymic mice. Nature, Lond. 278, 554-555.

West, J.D., Fredo, W.I., Papaioannou, V.E., Karr, J.P. \& Chapman, V. (1977) Development of interspecific hybrids of Mus. J. Embryol. exp. Morph. 41, 233-243.

West, J.D., Fredo, W.I. \& Chapman, V.E. (1978) Mus musculus and Mus caroli hybrids: mouse mules. $J$. Hered. 69, 321-326.

Wilson, A. \& Shortman, K. (1984) Degradation of specificity in cytolytic $T$. lymphocyte clones: mouse strain dependence and interstrain in transfer of non-specific cytolysis. Eur. J. Immunol. 14, 951-956.

Yoshimoto, R., Kashima, N., Okada, K., Amikura, K. \& Hamuro, J. (1985) Recombinant interleukin 2 differences alloantigen-primed Lyt-2+ T cells into the activated cytotoxic state. Eur. J. Immunol. 15, 325-331.

Youtananukorn, V., Matankasombut, P. \& Osathanondh, V. (1974) Onset of human maternal cell-mediated immune reaction to placental antigens during first pregnancy. Clin. exp. Immunol. 16, 593-598. 